he says, "but it was one of those things that eventually requirements [elsewhere in the agency] ate up."

Last October the CIA, at least partially aware of the problem, overhauled the directorate and established a new Office of Advanced Technologies and Programs, according to agency documents. In 1999 it had set up In-Q-Tel, a nonprofit organization designed to improve agency ties with start-up companies, where expertise in information technology is increasingly concentrated.

"The idea was to try and identify new, innovative information technologies that could be incubated with seed money from this organization," explains Hirsch.

In-Q-Tel was part of an effort by the CIA, which has no research laboratories of its own, to break its technical reliance on a small circle of contractors who know its way of working and conform with its secrecy requirements. The early results of the concept were "quite impressive", Richelson claims.

Far more rapid progress will now be expected, to get the CIA and other spy agencies abreast of terrorists' means of communication. Hirsch says that one typical requirement is for something similar to a web-browser, that would scour the US government's vast but fragmented and closely-held intelligence databases.

Security agencies have been tightlipped about their ability to monitor the Internet, but outside experts say that blanket monitoring of all the traffic on it is out of the question. There are "just way too much data to handle," says Richard Clayton, a computer scientist with the Computer Security Group at Cambridge University.

The monitoring of traffic to and from certain e-mail addresses and geographical locations is more feasible, and is already undertaken by systems such as the FBI's Carnivore programme, which picks up messages by physically tapping Internet nodes and surveys them for keywords or phrases of interest.

One of the most powerful approaches to monitoring e-mail, however, is to locate one of the computers that sent or received it. Documents and even decrypted and deleted e-mail messages can then be retrieved fairly easily, says Jim Bates, managing director of UKbased Computer Forensics.

Bates says that even supposed computer experts would be unable to cover their cyber-tracks completely. He recalls one case when $98 \%$ of the e-mail messages relating to a banking fraud case were found on the computers that had sent or received them, even though the hard drives had been reformatted.

Additional reporting by David Adam

\title{
Support for science is firm as emergency raises budget
}

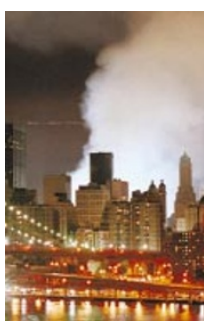

Matthew Davis, Washington

Faced with the terrorist attacks on New York and Washington, lawmakers have put aside disagreements over the dwindling budget surplus and agreed a bipartisan funding package that should increase spending on most science programmes.

The package would allow Congress to proceed with previously stalled funding bills for the 2002 fiscal year, starting on 1 October. If the deal is approved by the White House, it will provide, among other things, $\$ 2.8$ billion in further spending for the National Institutes of Health (NIH), and a boost of as much as $\$ 400$ million for the National Science Foundation.

The intensive effort to wrap up the bills next month is being assisted by a modest infusion of extra money. "The sense is that we have more money than we thought we would have just a few weeks ago," says one congressional aide, "but perhaps not as much as some ultimately would have hoped for at the end of the process."

Congress is already reviewing research and development programmes that could aid the US response to the terrorist attacks. It may choose to bolster them with a portion of the $\$ 40$ billion in emergency spending approved by Congress last week to deal directly with the attacks - or from further supplementary spending. Some have stated privately that the total bill for America's response to the attacks could come to several hundred billion dollars over an unspecified period of time.

President George W. Bush's administration was well on its way to finalizing the 2003 budget - which Bush will present next February - at the time of the attacks, but this will now be subject to drastic revision.

A House of Representatives panel that handles budgets for the NIH and the Centers for Disease Control and Prevention (CDC) met just three days after the attacks to review spending on programmes related to bioterrorism. The chair of the panel, Ralph Regula (Republican, Ohio), says that he expects Bush to allocate some of the emergency money to the CDC's civilian anti-bioterrorism activities, which involve both research and public-health initiatives. Regula thinks the Bush administration's plan to spend $\$ 181$ million on CDC measures to combat bioterrorism in 2002 may be inadequate.

It is unclear whether the NIH might obtain more funding for bioterrorism projects. The government was already set to

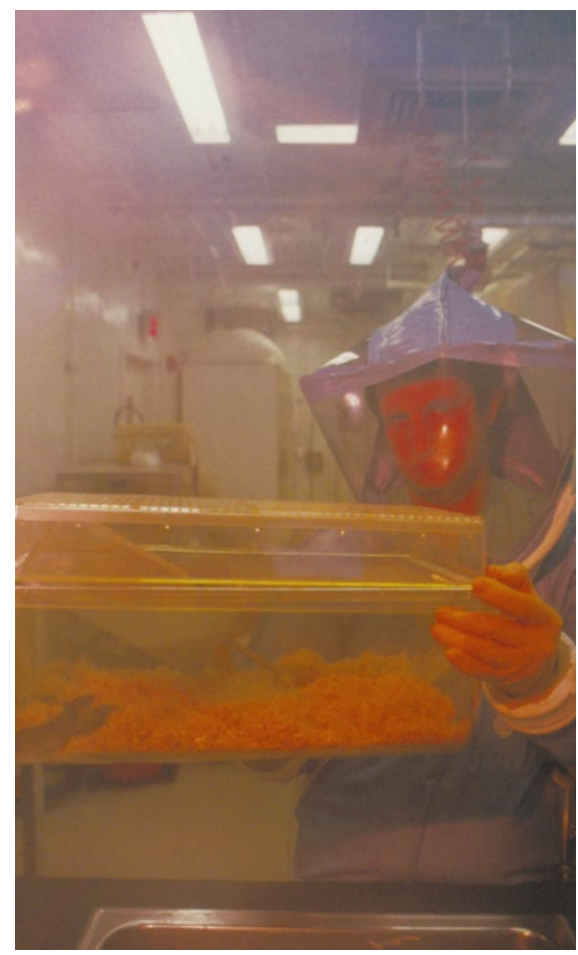

High security: bioterrorism work at the Centers for Disease Control is set to gain impetus.

increase its budget from $\$ 49$ million to $\$ 93$ million next year. The work, which includes sequencing the genomes of potential bioterror agents, is aimed largely at developing better vaccines and diagnostic tests.

According to government officials, other candidates for emergency funding include secret military and security-related research programmes ('black-box' programmes) at Department of Energylaboratories.

A congressional aide who works with science programmes notes that as Congress reviews research, there will be a strong temptation to portray programmes as being relevant to counter-terrorism. "Everyone will recast what they're doing so it looks indirectly or directly related to this," he says.

Before the attack, Mitch Daniels, director of the White House Office of Management and Budget, had been asking agencies to cut their budgets by $5 \%$ in 2003 . But he had indicated that the White House would consider boosting non-biomedical research funding.

That will now have to be weighed against the requirements of a global military campaign, rebuilding in New York and Washington, and coping with the growing demands for social spending and revenue losses related to the ensuing economic downturn.

"The outlook for 2003 spending has been completely scrambled," said one of the congressional aides. "All bets are off." 